\title{
Ovarian morphology and the concentration of steroids, and of gonadotrophins during the breeding season in ewes actively immunized against oestradiol-17 $\beta$ or oestrone
}

\author{
R. J. Scaramuzzi*†, N. D. Martensz $\dagger \ddagger$ and P. F. A. Van Look $\dagger \S$ \\ ${ }^{*}$ CSIRO, Division of Animal Production, P.O. Box 239, Blacktown, New South Wales 2148, \\ Australia, and $\dagger$ M.R.C. Unit of Reproductive Biology, 37 Chalmers Street, \\ Edinburgh EH3 9EW, U.K.
}

\begin{abstract}
Summary. Ewes were actively immunized against oestrone-6-(O-carboxymethyl)oxime-bovine serum albumin, 17 $\beta$-oestradiol-6-(O-carboxymethyl)oxime-bovine serum albumin or bovine serum albumin (controls). All 4 control ewes, 1 of 5 oestradiol-immunized ewes and 1 of 5 oestrone-immunized ewes had regular oestrous cycles. The other animals displayed oestrus irregularly or remained anoestrous. The plasma concentrations of $\mathrm{LH}$ and, to a lesser degree, FSH were increased relative to those in control ewes on Days 11-12 after oestrus or a similar total period after progestagen treatment in ewes not showing oestrus.

The ovaries were examined and jugular venous blood, ovarian venous blood and follicular fluid were collected at laparotomy on Days 9-10 of the oestrous cycle. The ovaries of immunized ewes were heavier than those of control ewes. There were no $\mathrm{CL}$ in 5 of the immunized ewes but in the other 5 there were more CL than in the control ewes. Ovaries from 4 of 5 oestrone-immunized ewes contained luteinized follicles, while ovaries from 4 of 5 oestradiol-immunized ewes contained very large follicles with a degenerated granulosa and a hyperplastic theca interna. Both types of follicles produced progesterone, detectable in ovarian venous plasma and production of other steroids, particularly androstenedione, was also increased. The steroidbinding capacity of plasma was increased in the immunized ewes. The binding capacity of follicular fluid for oestradiol-17 $\beta$ and oestrone was similar to that of jugular venous plasma from the same ewes.

These results suggest that immunization against oestrogens disrupts reproductive function by interfering with the feedback mechanisms controlling gonadotrophin secretion.
\end{abstract}

\section{Introduction}

Active immunization of female sheep against oestrogens produces a castration-like effect on pituitary function (Scaramuzzi et al., 1977; Pant, Dobson \& Ward, 1978; Rawlings, Kennedy \& Henricks, 1978; Martensz, Scaramuzzi \& Van Look, 1979). The basal levels of both luteinizing hormone ( $\mathrm{LH})$ and follicle-stimulating hormone (FSH) and the frequency of pulsatile LH release increase to levels similar to those seen in ovariectomized animals. Immunized ewes rapidly develop an anovulatory condition (Cox, Wilson \& Mattner, 1976; Scaramuzzi et al., 1977) due U.K.

$\ddagger$ Present address: Department of Anatomy, University of Cambridge, Downing Street, Cambridge CB2 3DY,

$\S$ Present address: Vrouwenkliniek, Academisch Ziekenhuis Leiden, Rijnsburgerweg 10, Leiden, The Netherlands. 
to a failure of positive feedback (Scaramuzzi, Caldwell, Tillson \& Thorneycroft, 1970; Pant $e t$ al., 1978). The present paper examines the effects of the high endogenous levels of gonadotrophins in ewes immunized against oestradiol-173 or oestrone on follicular morphology and ovarian steroid secretion.

\section{Materials and Methods}

\section{Immunization procedures}

During November 1974, adult Welsh Mountain ewes were actively immunized with $1.9 \mathrm{mg}$ of either 17ß-oestradiol-6-(O-carboxymethyl)oxime-bovine serum albumin (oestradiol-6-BSA) (5 ewes) or oestrone-6-(O-carboxymethyl)oxime-bovine serum albumin (oestrone-6-BSA) (5 ewes) in Freund's complete adjuvant (Scaramuzzi, Corker, Young \& Baird, 1975; Martensz, 1977). The animals were given booster immunizations in February $1975(2.0 \mathrm{mg}$ oestradiol6-BSA or $1.6 \mathrm{mg}$ oestrone-6-BSA) and August 1975 (2.1 mg oestradiol-6-BSA or $1.1 \mathrm{mg}$ oestrone-6-BSA). A control group of 4 ewes was immunized against bovine serum albumin (BSA) at the same times.

\section{Collection of blood samples}

During September 1975, the ewes were treated with intravaginal progestagen pessaries (Synchromate: G. D. Searle \& Co., High Wycombe, Bucks). After removal of the pessaries, harnessed vasectomized rams were introduced to the flock for detection of oestrus; all the control ewes, 1 oestradiol-immunized ewe and 1 oestrone-immunized ewe began to cycle regularly. The other animals remained anoestrous or displayed oestrus irregularly.

Blood samples $(5 \mathrm{ml})$ were collected from indwelling jugular cannulae at 15 -min intervals for a period of $6 \mathrm{~h}$ (12:00-18:00 h) on Days 11-12 of the second oestrous cycle after removal of the progestagen pessaries or 30 days after removal of pessaries in the anoestrous animals, assuming they had ovulated in synchrony with the ovulatory ewes.

During the third oestrous cycle after removal of progestagen pessaries, laparotomies were performed on Days 9-10 (or an equivalent day, i.e. 48 days after removal of the pessaries, in the anoestrous animals). Ovarian venous blood $(20 \mathrm{ml})$ was collected from both ovaries either by cannulation of the ovarian vein (Baird \& Scaramuzzi, 1976) or by direct aspiration into a 20-ml syringe (Scaramuzzi \& Land, 1978). A sample of jugular venous blood was collected at the same time. Follicular fluid was aspirated from large follicles $\geqslant 5 \mathrm{~mm}$ diameter) present in the ovaries of the immunized animals. Fluids from the larger follicles $\geqslant 7 \mathrm{~mm}$ were kept separate and fluids from the smaller follicles (5-6 mm diameter) were pooled within ovaries. The animals were then killed and the ovaries, the adrenal glands and the pituitary gland were removed and weighed. The whole reproductive tract was removed intact from 1 oestradiol-immunized ewe and placed in formol-saline.

\section{Histology}

Corpora lutea were dissected from the ovaries. The corpora lutea and the remainder of the ovary were placed separately in Bouin's fixative for $24 \mathrm{~h}$; all tissues were then stored in $70 \%$ ethanol. The tissues were embedded in paraffin wax and sectioned at $15 \mu \mathrm{m}$ thickness. Representative sections were stained with haematoxylin and eosin for examination under a light microscope.

\section{Assay procedures}

Blood samples were collected in heparinized tubes and the plasma was removed after centrifugation and stored at $-20^{\circ} \mathrm{C}$ until assayed. Follicular fluids were also stored at $-20^{\circ} \mathrm{C}$.

Ovine LH was measured by a specific double-antibody radioimmunoassay (Martensz, Baird, Scaramuzzi \& Van Look, 1976) using ovine NIH-LH-S14 as the reference standard and an 
ovine LH preparation (LER-1374A, provided by Dr L. E. Reichert, Jr, Emory University, Atlanta, Georgia, U.S.A.) for iodination. Ovine FSH was measured by a heterologous radioimmunoassay (Lincoln, Peet \& Cunningham, 1977) using ovine NIH-FSH-S10 as the reference standard and a rat pituitary FSH preparation (NIAMD-Rat-FSH-I-3) for iodination.

All samples taken from a single animal were assayed in duplicate within a single assay. The intra-assay coefficients of variation were 8 and $5 \%$ for the LH and FSH assays respectively. Interassay coefficients of variation, assessed by the inclusion of pooled samples of ovine plasma in each assay, were $15 \%$ (mean \pm s.d.: $1.40 \pm 0.21 \mathrm{ng} \mathrm{LH} / \mathrm{ml}, n=24)$ and $8 \%(21.6 \pm 0.33$ ng $\mathrm{FSH} / \mathrm{ml}, n=17$ ) for the $\mathrm{LH}$ and $\mathrm{FSH}$ assays respectively. $\mathrm{LH}$ was measured in all samples taken during the intensive sampling period. FSH was measured in alternate samples from all the oestradiol-immunized ewes and 3 animals from each of the control and oestrone-immunized groups.

Ovarian venous plasma and jugular venous plasma were acidified with $1 \mathrm{~N}-\mathrm{HCl}$ and the steroid levels were determined using radioimmunoassays described in detail in other publications; oestrone, oestradiol-17 $\beta$ and androstenedione (Baird, Burger, Heavon-Jones \& Scaramuzzi, 1974; Scaramuzzi et al., 1975; Baird, Swanston \& Scaramuzzi, 1976); testosterone (Corker \& Davidson, 1978); and progesterone (Scaramuzzi et al., 1975).

The characteristics of the assays used in the present analyses are as follows:

$\begin{array}{lccr}\text { Antiserum } & \begin{array}{c}\text { Inter-assay } \\ \text { precision }\end{array} & \begin{array}{c}\text { Limit of } \\ \text { sensitivity }\end{array} \\ \text { Oestrone } & 029-14 & 12 \% & 10 \mathrm{pg} / \mathrm{ml} \\ \text { Oestradiol-17 } & - & 9.5 \% & 10 \mathrm{pg} / \mathrm{ml} \\ \text { Androstenedione } & \text { Schopman } & 15 \% & 150 \mathrm{pg} / \mathrm{ml} \\ \text { Testosterone } & \mathrm{E} 01 & 11.5 \% & 10 \mathrm{pg} / \mathrm{ml} \\ \text { Progesterone } & 91920 / 9 & 13 \% & 200 \mathrm{pg} / \mathrm{ml}\end{array}$

The antiserum used for the assay of the oestradiol fraction was a specific one raised against the 17ß-oestradiol-6-(O-carboxymethyl)oxime-BSA (Dean, Exley \& Johnson, 1971; Van Look, Hunter, Corker \& Baird, 1977).

The capacity of jugular venous plasma and follicular fluid to bind tritiated steroids was determined without prior acidification of the fluid using a dextran-charcoal radioassay (Scaramuzzi et al., 1975).

\section{Statistical procedures}

The concentrations of steroids in ovarian venous plasma were analysed using a split plot analysis of variance. The main plot treatments were immunization against steroids and sub-plots were formed by the side from which ovarian venous plasma was collected. Before analysis concentrations of steroids in ovarian and jugular venous plasma were transformed to logarithms to overcome heterogeneity of variance. Data on ovulation rate were analysed using Fisher's exact test, and on the number of follicles using Wilcoxon's rank sum test. The remaining data were analysed using $t$ tests.

\section{Results}

All the control ewes were in oestrus $2-3$ days after removal of the pessaries and experienced regular oestrous cycles up to the time of laparotomy. Only 1 ewe immunized against oestradiol-6-BSA and 1 ewe immunized against oestrone-6-BSA had regular oestrous cycles. Of the remaining 8 animals, 3 ewes immunized against oestrone-6-BSA displayed oestrus irregularly ( $>25$ days) while the others ( 1 oestrone-immunized and 4 oestradiol-immunized) remained anoestrous. 
Laparotomy revealed that the 5 anoestrous ewes were also anovulatory as indicated by the absence of corpora lutea (Table 1). The ovaries of these animals contained numerous very large (>10 mm diameter), abnormal follicles, of which some were thin-walled and fluid-filled, while others had thickened walls (PI. 1, Figs 1, 2 and 7; PI. 2, Figs 8 and 9). The 5 immunized ewes that had ovulated did not have any follicles $\geqslant 10 \mathrm{~mm}$ diameter present in their ovaries and had a greater number of corpora lutea and smaller $(3-10 \mathrm{~mm}$ ) follicles than did the controls (Table 1 ). Ovarian weight was increased in both groups of immunized ewes and adrenal weight was increased in the ewes immunized against oestrone (Table 1).

Table 1. The number of ewes showing oestrus and ovulation and the mean ( \pm s.e.m.) ovulation rate, follicle number, and weights of ovaries, corpora lutea (CL), adrenal and pituitary glands during the breeding season of ewes immunized against oestradiol-6-BSA, oestrone-6-BSA or BSA (controls)

\begin{tabular}{lccc}
\hline & \multicolumn{3}{c}{ Treatment group } \\
\cline { 2 - 4 } & $\begin{array}{c}\text { Oestradiol-6-BSA } \\
(\mathrm{N}=5)\end{array}$ & $\begin{array}{c}\text { Oestrone-6-BSA } \\
(\mathrm{N}=5)\end{array}$ \\
\hline No. of ewes showing regular oestrus & 1 & 1 & 4 \\
No. of ewes ovulating (CL present at laparotomy) & 1 & 4 & 4 \\
Ovulation rate (of ewes ovulating) & 3.0 & $3.0 \pm 0.4^{*}$ & $1.5 \pm 0.2$ \\
Wt of each ovary (g) & $4.98 \pm 1.78^{*}$ & $1.99 \pm 0.23^{*}$ & $1 \cdot 19 \pm 0.18$ \\
Wt of each CL (g) & $0.47 \pm 0.01$ & $0.63 \pm 0.05$ & $0.50 \pm 0.05$ \\
No. of visible surface follicles $\geqslant 3$ mm diam. & $8.2 \pm 1.3^{* *}$ & $9.2 \pm 1.5^{* *}$ & $1.2 \pm 0.3$ \\
Wt of each adrenal gland (g) & $1.77 \pm 0.11$ & $2.88 \pm 0.13^{* *}$ & $1.71 \pm 0.09$ \\
Wt of pituitary gland (mg) & $549 \pm 43$ & $519 \pm 52$ & $667 \pm 75$ \\
\hline
\end{tabular}

Values significantly different from that for controls: ${ }^{*} P<0.05 ;^{* *} P<0.01$.

The mean concentrations of LH and FSH during the intensive sampling period in the control and immunized ewes are shown in Text-fig. 1. LH was increased in 3 ewes immunized against oestradiol-6-BSA and in all animals immunized against oestrone-6-BSA. FSH was increased in 2 of 5 oestradiol-immunized ewes and in 2 of 3 oestrone-immunized animals.

The concentrations of steroids in ovarian venous and jugular venous plasma varied markedly among immunized animals (Table 2), largely reflecting the heterogeneity of the immune

Table 2. The mean ( \pm s.e.m.) concentrations of steroids in ovarian venous and jugular venous plasma during the breeding season in sheep actively immunized against oestradiol-6-BSA, oestrone-6-BSA or BSA (control)

\begin{tabular}{|c|c|c|c|c|}
\hline & \multirow[b]{2}{*}{ Vein } & \multicolumn{3}{|c|}{ Treatment group } \\
\hline & & $\begin{array}{c}\text { Oestradiol-6-BSA } \\
\text { anovulatory ewes } \\
\quad(N=4)\end{array}$ & $\begin{array}{l}\text { Oestrone-6-BSA } \\
\text { Day 10 } \\
(\mathrm{N}=5)\end{array}$ & $\begin{array}{c}\text { BSA, } \\
\text { Day } 10 \\
(\mathrm{~N}=4)\end{array}$ \\
\hline Oestrone $(\mathrm{pg} / \mathrm{ml})$ & $\begin{array}{l}\text { Ovarian } \\
\text { Jugular }\end{array}$ & $\begin{array}{l}606 \pm 179^{* *} \\
\text { No data }\end{array}$ & $\begin{array}{c}\text { No data } \\
2021 \pm 766^{* * * *}\end{array}$ & $\begin{array}{c}109 \pm 18 \\
19 \pm 2\end{array}$ \\
\hline Oestradiol-17 $\beta(\mathrm{pg} / \mathrm{ml})$ & $\begin{array}{l}\text { Ovarian } \\
\text { Jugular }\end{array}$ & $\begin{array}{l}\text { No data } \\
982+297^{* * * *}\end{array}$ & $\begin{array}{l}155 \pm 48 \\
124+39^{*}\end{array}$ & $\begin{array}{l}59 \pm 13 \\
33+4\end{array}$ \\
\hline Androstenedione $(\mathrm{pg} / \mathrm{ml})$ & $\begin{array}{l}\text { Ovarian } \\
\text { Jugular }\end{array}$ & $\begin{array}{c}19660 \pm 6136^{* *} \\
301 \pm 72\end{array}$ & $\begin{array}{l}3125 \pm 1297^{* *} \\
179 \pm 40\end{array}$ & $\begin{array}{l}339 \pm 62 \\
125 \pm 72\end{array}$ \\
\hline Testosterone (pg/ml) & $\begin{array}{l}\text { Ovarian } \\
\text { Jugular }\end{array}$ & $\begin{array}{r}434 \pm 95 \\
99 \pm 27\end{array}$ & $\begin{array}{l}317 \pm 28 \\
123 \pm 22^{*}\end{array}$ & $\begin{array}{r}217 \pm 54 \\
44 \pm 15\end{array}$ \\
\hline $\begin{array}{l}\text { Progesterone (ng/ml) (ovary with } \\
\text { CL) }\end{array}$ & $\begin{array}{l}\text { Ovarian } \\
\text { Jugular }\end{array}$ & $\begin{array}{l}358 \pm 65 \dagger \\
1.9 \pm 1.0 \dagger\end{array}$ & $\begin{array}{l}698 \pm 81 \\
10 \cdot 9 \pm 2 \cdot 0^{* * *}\end{array}$ & $\begin{array}{l}582 \pm 138 \\
3 \cdot 1 \pm 0 \cdot 2\end{array}$ \\
\hline
\end{tabular}
data).

Values significantly different from that for controls: ${ }^{*} P<0.05 ;{ }^{* *} P<0.01 ;{ }^{* * *} P<0.001$ (log transformed

$\dagger$ Ovaries without $\mathrm{CL}$, but luteinized follicles present. 
PLATE 1
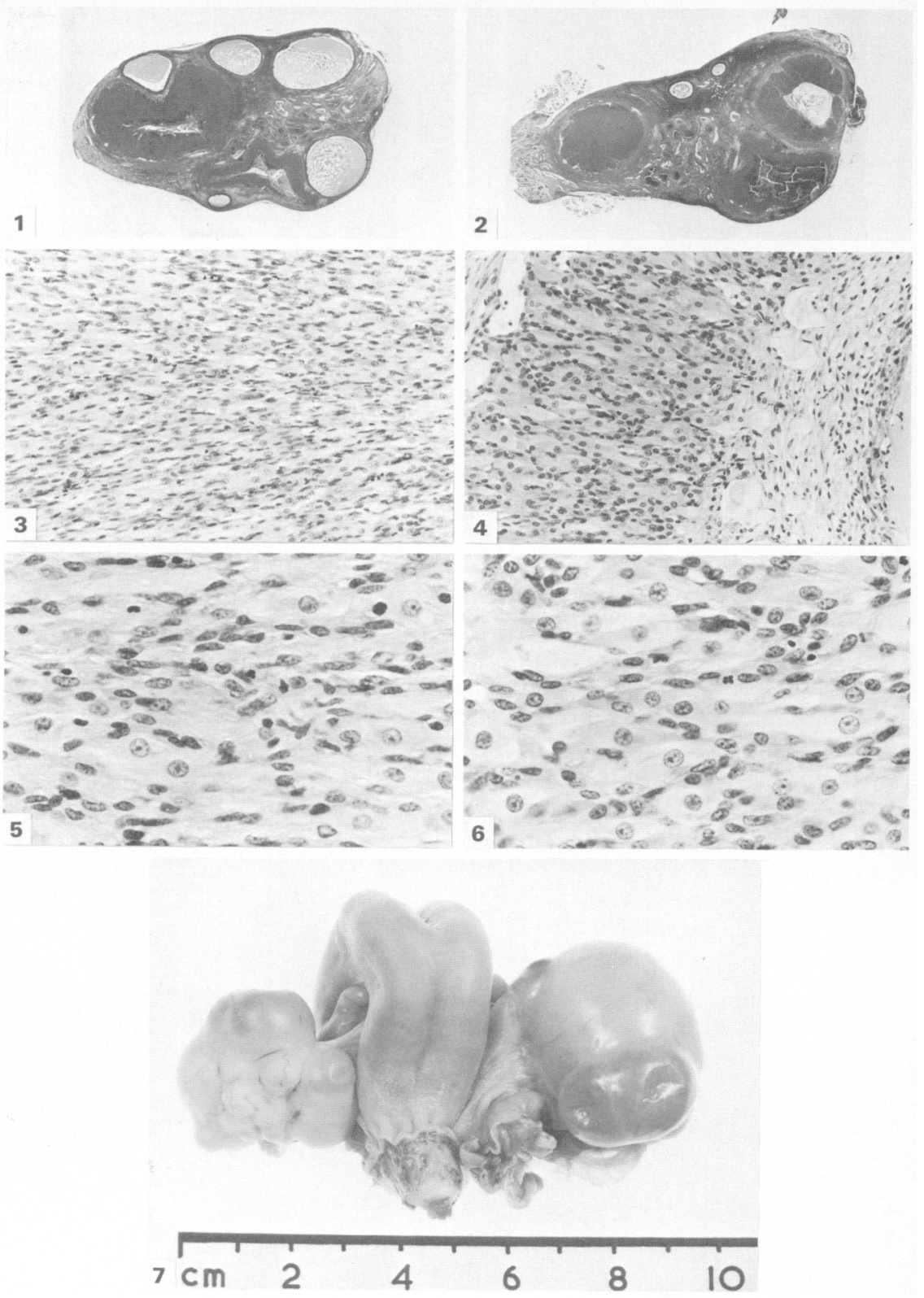

Figs 1 and 2. Sections $(\times 2 \cdot 2)$ of left and right ovaries from Ewe 10 immunized against oestrone-6-BSA. The ewe was anovulatory at the time of laparotomy and had last shown oestrus 28 days earlier.

Figs 3 and 5. Detail of the luteinized wall of a follicle in the ovary in Fig. $1 . \times 110$ (Fig. 3); $\times 280$ (Fig. 5).

Figs 4 and 6. Detail of an abnormal corpus luteum enucleated at laparotomy 27 days after oestrus from a ewe (No. 11) immunized against oestrone-6-BSA. $\times 110$ (Fig. 4); $\times 280$ (Fig. 6).

Fig. 7. Reproductive tract of a ewe (No. 9) immunized against oestradiol-6-BSA. This ewe was anovulatory and had grossly enlarged ovaries but a uterus of normal appearance. 


\section{PLATE 2}

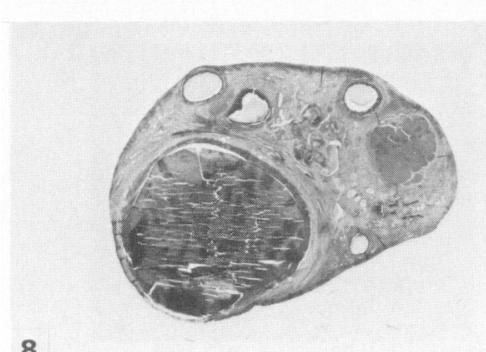

8
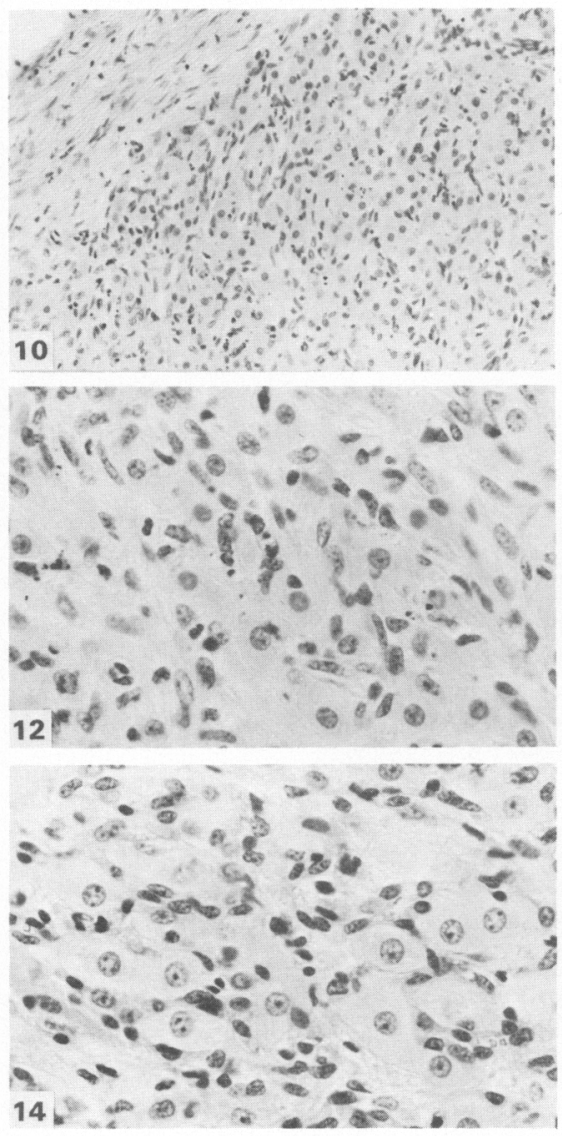

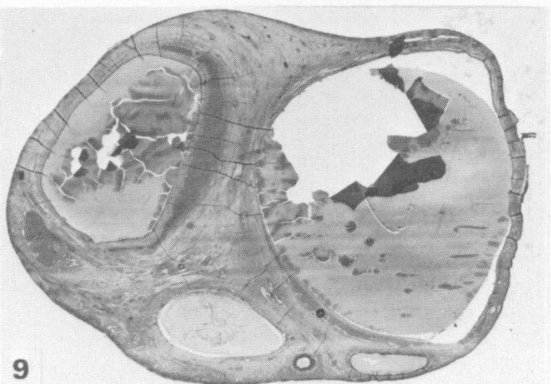

9
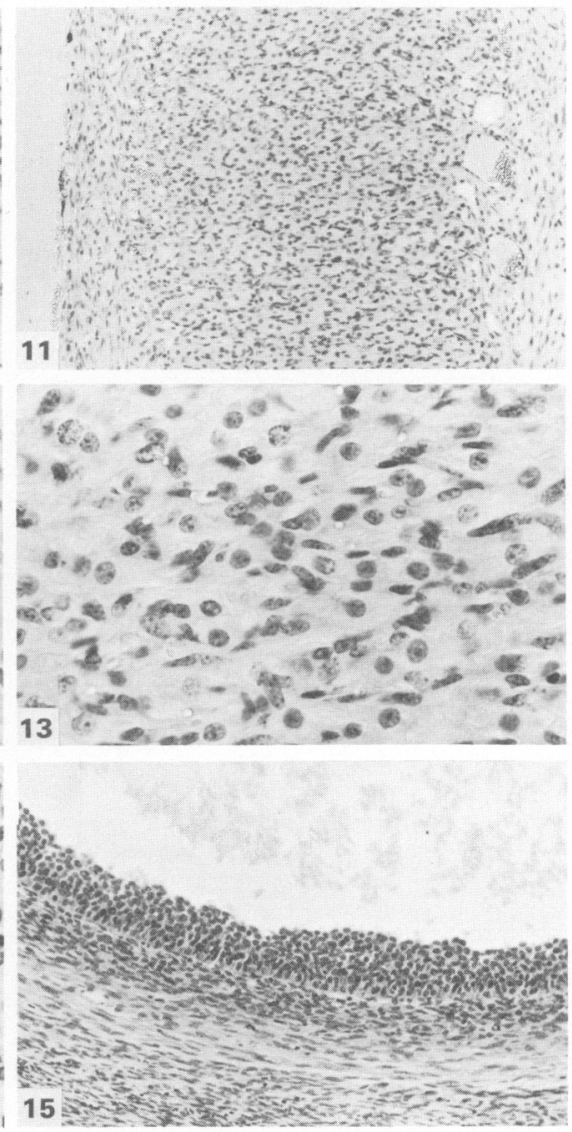

Ovarian tissue from ewes immunized against oestradiol-6-BSA.

Figs 8 and 9. Sections of ovaries $(\times 4.4)$ from 2 ewes (Nos 6 and 8 ) which were anovulatory and had large abnormal follicles with a degenerated membrana granulosa and a hyperplastic theca interna.

Figs 10 and 12. Wall of an abnormal follicle from the ovary shown in Fig. $9 . \times 110$ (Fig. 10); $\times 280$ (Fig. 13).

Figs 11 and 13. Wall of an abnormal follicle from the ovary shown in Fig. 8. $\times 70$ (Fig. 11); $\times 280$ (Fig. 13).

Figs 14 and 15. Normal corpus luteum and normal follicle wall from a ewe (No. 5) which continued to have regular oestrous cycles after immunization. $\times 280$ (Fig. 14); $\times 110$ (Fig. 15). 


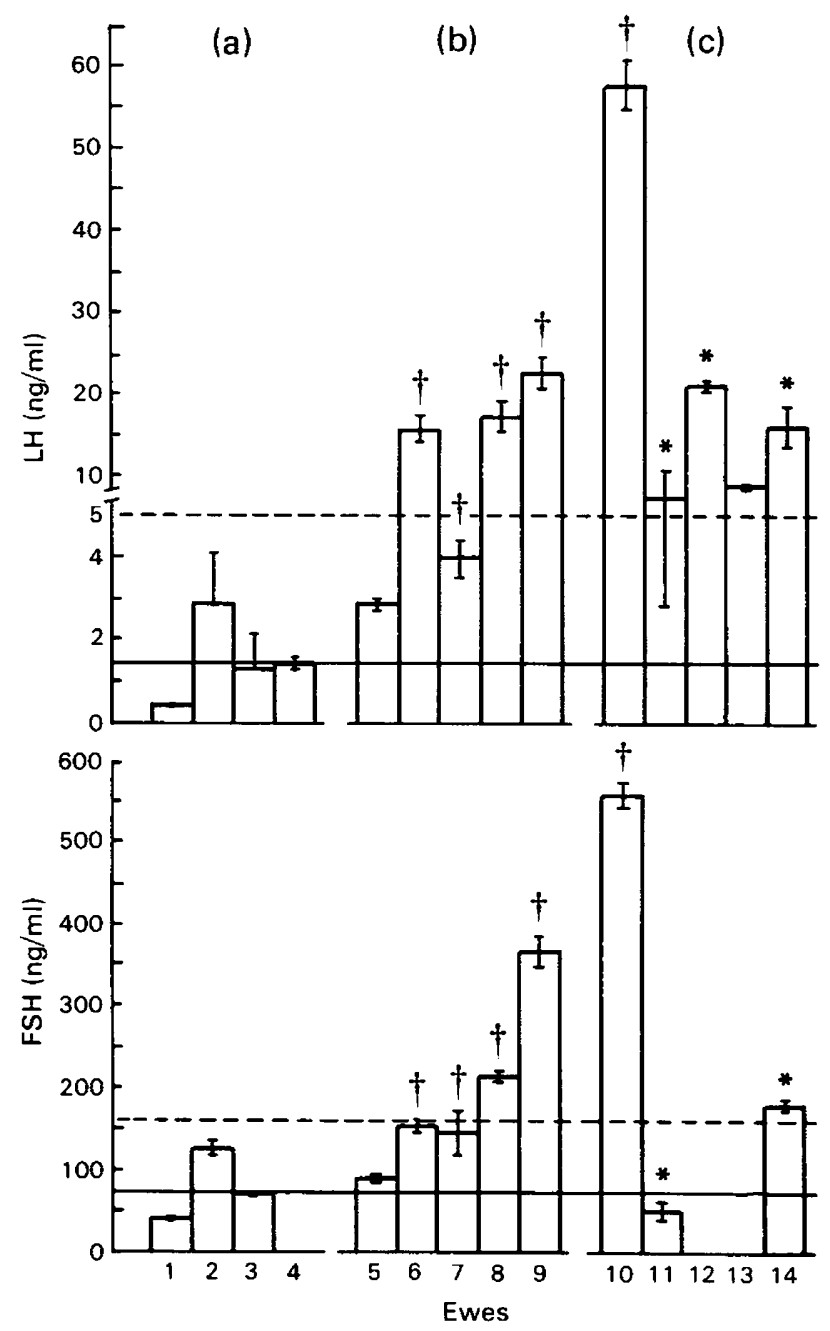

Text-fig. 1. Mean \pm s.e.m. concentrations of $\mathrm{LH}$ and FSH in jugular venous plasma during the breeding season in ewes immunized against (a) BSA (controls); (b) oestradiol-6-BSA; (c) oestrone-6-BSA. Samples were taken at 15-min intervals for $6 \mathrm{~h}(12: 00-18: 00 \mathrm{~h})$ on Days 11-12 after oestrus or an 'equivalent' day in anoestrous ewes, assuming that they had ovulated in synchrony with the controls. LH was measured in all samples. FSH was measured in alternate samples for the 5 oestradiol-immunized ewes and 3 animals from each of the control and oestrone-immunized groups. The horizontal solid lines represent the mean and the broken lines two standard deviations above the mean levels in the controls. ${ }^{*}$ Ewes displaying irregular oestrus. † Anovulatory ewes.

responses. Nevertheless, the means of the treatment groups showed an overall trend of increased steroid secretion. The ewe immunized against oestradiol-6-BSA and having regular oestrous cycles had hormone concentrations similar to those in the control ewes. All other immunized ewes had, to various degrees, abnormally high steroid concentrations in both jugular and ovarian venous plasma. The net secretion of androstenedione (difference in concentrations between ovarian venous and jugular venous plasma) was increased in 9 ewes and in 6 ewes the net secretion of oestradiol, oestrone and testosterone was also increased. There was a substantial secretion of progesterone into the ovarian vein from ovaries containing either corpora lutea or 
large abnormal follicles, indicating that these large follicles were luteinized and capable of secreting quantities of progesterone similar to those secreted by a normal corpus luteum (Table 2).

Histological examination of the ovaries of the 5 ewes immunized against oestrone showed the presence of abnormal follicles with thickened and luteinized walls (PI. 1, Figs 3 and 5) in the 1 anovulatory ewe. Despite the absence of corpora lutea the right and left ovarian veins of this ewe contained 372 and $308 \mathrm{ng}$ progesterone/ml respectively. Examination of the corpora lutea from the other oestrone-immunized ewes indicated that some were abnormal (Pl. 1, Figs 4 and 6) and may not have formed as a consequence of ovulation. Large luteinized follicles were also present in these animals. Immunization against oestradiol-6-BSA resulted in very large abnormal follicles with severe degeneration of the granulosa, no visible basement membrane and hyperplasia of the theca interna in each of the 4 oestradiol-immunized ewes that were anovulatory (Pl. 2, Figs 10-13). The 2 immunized ewes (1 oestrone-immunized, and 1 oestradiol-immunized) that continued regular oestrous cycles had ovaries of normal size and with normal follicles and corpora lutea (Pl. 2, Figs 14 and 15).

All of the immunized ewes produced antibodies to their respective steroid haptens and these antibodies could be readily detected in jugular venous plasma (Table 3). Although the specificity of the antibody response was directed towards the steroid hapten, antibodies to other steroids were present in lesser quantities (Table 3). The lack of absolute specificity was confirmed by the elevated peripheral concentrations in the absence of increased ovarian secretion of some steroids in some immunized ewes (Table 2). The binding capacity of follicular fluid for steroid haptens was similar to that of jugular venous plasma; at a dilution of $1: 200$, plasma and follicular fluid from ewes immunized against oestrone-6-BSA bound $78 \pm 2 \%$ (s.e.m., $n=4$ ) and $74 \pm 3 \%$ $(n=11)$ of $15-20 \mathrm{pg}$ of added $\left[{ }^{3} \mathrm{H}\right]$ oestrone, respectively. Similarly, plasma and follicular fluid from ewes immunized against oestradiol-6-BSA bound $73 \pm 2 \%(n=4)$ and $72 \pm 2 \%(n=14)$ of added $\left[{ }^{3} \mathrm{H}\right]$ oestradiol, respectively.

Table 3. The reciprocal mean and range of antibody titres of four tritiumlabelled steroids (10-15 pg) in jugular venous plasma obtained during the breeding season from sheep immunized against oestradiol-6-BSA, oestrone-6BSA or BSA (controls)

\begin{tabular}{|c|c|c|c|}
\hline \multirow[b]{2}{*}{ Radio ligand } & \multicolumn{3}{|c|}{$\begin{array}{l}\text { Reciprocal antibody titre } \\
\text { (the dilution binding } 50 \% \text { of added radio ligand) }\end{array}$} \\
\hline & $\begin{array}{l}\text { Oestradiol-6-BSA } \\
\quad(\mathrm{N}=5)\end{array}$ & $\begin{array}{l}\text { Oestrone-6-BSA } \\
\quad(N=5)\end{array}$ & $\begin{array}{c}\text { BSA } \\
(\mathrm{N}=4)\end{array}$ \\
\hline Oestrone & $\begin{array}{c}1400 \\
(30-2700)\end{array}$ & $\begin{array}{c}3380 \\
(1300-5000)\end{array}$ & $<1$ \\
\hline Oestradiol-17 $\beta$ & $\begin{array}{c}3470 \\
(950-6200)\end{array}$ & $\begin{array}{c}203 \\
(32-420)\end{array}$ & $<1$ \\
\hline Androstenedione & $\begin{array}{r}3 \\
(1-6)\end{array}$ & $\begin{array}{c}11 \\
(4-20)\end{array}$ & $<1$ \\
\hline Testosterone & $\begin{array}{c}56 \\
(7-200)\end{array}$ & $\begin{array}{c}72 \\
(2-280)\end{array}$ & $\begin{array}{r}<1 \\
(<1-2)\end{array}$ \\
\hline
\end{tabular}

\section{Discussion}

Immunization against oestradiol-6-BSA or oestrone-6-BSA resulted in increased plasma binding capacity for all 4 steroids examined. The immune response was directed primarily towards the respective steroid hapten with a considerably lower binding capacity for the other steroids tested. For oestradiol or oestrone the binding capacity of jugular venous plasma and 
follicular fluid from immunized ewes was similar, indicating that antibodies were present within the ovarian follicles (Edwards, 1974). The increased binding of steroids was sufficient to delay or completely block oestrus and ovulation in 4 of 5 ewes from each immunized group. The degree of this disruption was related to the antibody titre in the ewes immunized against oestradiol-6-BSA but apparently not in those immunized against oestrone-6-BSA (Martensz, 1977). The mechanisms underlying these effects are not known.

Immunization against oestrogens resulted in highly variable but generally increased plasma levels of LH and FSH, probably through a reduced negative feedback action of oestrogens on gonadotrophin secretion (Pant et al., 1978; Rawlings et al., 1978; Martensz et al., 1979). In these animals $\mathrm{LH}$ release was pulsatile and similar to the patterns previously reported for immunized seasonally anoestrous sheep (Martensz et al., 1979). These increases in gonadotrophin secretion are probably responsible for the increases in follicular development and ovarian weight in the anovulatory ewes. Polycystic ovaries have also been found in female rats immunized against oestradiol-6-BSA (Hillier \& Cameron, 1976). Gonadotrophins stimulate the secretion of androgens and oestrogens from the ovary (Baird, Goding, Ichikawa \& McCracken, 1968; McCracken, Uno, Goding, Ichikawa \& Baird, 1969). Although it was not possible to determine ovarian steroid secretion rates in the present study, an estimate of steroid production may be obtained by subtraction of the steroid levels in jugular venous plasma from those found in ovarian venous plasma (Table 2). The increased levels of gonadotrophins are associated with increased production of ovarian steroids, especially of androstenedione. This is consistent with the hyperplasia seen in the theca interna (Pl. 2, Figs 10-13), which is the major source of androgens within the follicle (Moor, 1977). With the ready availability of androgen precursors and the increased levels of LH and FSH, the increase in oestrogen production was not as great as might have been expected (McCracken et al., 1969; Makris \& Ryan, 1975; Dorrington, Moon \& Armstrong, 1975). Perhaps the LH levels were high enough to inhibit oestrogen synthesis (Moor, 1974). Alternatively, the distribution of the thecal and granulosa cell layers may have disturbed the interaction between these cell types which is required for optimum oestrogen synthesis (Short, 1962; YoungLai \& Short, 1970; Baird, 1977; Moor, 1977).

The elevated gonadotrophin levels did not stimulate luteal function as there was no increase in the weight of corpora lutea or progesterone levels in ovarian venous plasma from the ovulatory immunized ewes. This supports the hypothesis that the normal corpus luteum is refractory to additional LH stimulation (Collett, Land \& Baird, 1973). There was, however, some alteration of the structure of the corpus luteum in the ewes immunized against oestrone-6-BSA and this was probably caused by the very high endogenous gonadotrophin levels in these animals. The concentrations of progesterone in avarian venous plasma were similar in the anovulatory and ovulatory immunized ewes, suggesting that the high levels of gonadotrophins may have caused luteinization of follicles in the anovulatory ewes.

The present study describes the marked effects active immunization against oestrogens may have on gonadotrophin secretion and on the morphology of Graafian follicles and the secretory activity of the ovary. The net effect of immunization was to alter reproductive function, resulting in either an anovulatory condition or an increased ovulation rate. The degree to which these changes in ovarian function are related to the high endogenous gonadotrophin levels or to a direct action of the antibodies themselves remains to be determined. Nevertheless, if the immune response could be controlled, it might be possible to increase ovulation rate without the deleterious effects on reproductive function.

The technical assistance of D. W. Davidson, W. G. Davidson, I. Maddocks and I. Swanston is gratefully acknowledged. The oestrone-6-(O-carboxymethyl)oxime-BSA and oestradiol6-(O-carboxymethyl)oxime-BSA conjugates were prepared by Dr P. D. G. Dean, University of Liverpool, Cheshire, U.K. P.F.A. Van L. was supported by the Nationaal Fonds voor Wetenschappelijk Ondersoek, Brussels, Belgium. 


\section{References}

Baird, D.T. (1977) Evidence in vivo for the two-cell hypothesis of oestrogen synthesis by the sheep Graafian follicle. J. Reprod. Fert. 50, 183-185.

Baird, D.T. \& Scaramuzzi, R.J. (1976) The source of ovarian oestradiol and androstenedione in the sheep during the luteal phase. Acta endocr., Copenh. 83, 402-409.

Baird, D.T., Goding, J.R., Ichikawa, Y. \& McCracken, J.A. (1968) The secretion of steroids from the autotransplanted ovary in the ewe spontaneously and in response to systemic gonadotrophin. J. Endocr. 42, 283-299.

Baird, D.T., Burger, P.E., Heavon-Jones, G.D. \& Scaramuzzi, R.J. (1974) The site of secretion of androstenedione in non-pregnant women. $J$. Endocr. 63, 201-212.

Baird, D.T., Swanston, I. \& Scaramuzzi, R.J. (1976) Pulsatile release of $\mathbf{L H}$ and secretion of ovarian steroids in sheep during the luteal phase of the oestrous cycle. Endocrinology 98, 1490-1496.

Collett, R.A., Land, R.B. \& Baird, D.T. (1973) The pattern of progesterone secretion by the autotransplanted ovary of the ewe in response to ovine luteinizing hormone. J. Endocr. 56, 403-411.

Corker, C.S. \& Davidson, D.W. (1978) A radioimmunoassay for testosterone in various biological fluids without chromatography. J. Steroid Biochem. 9, 373-374.

Cox, R.I., Wilson, P.A. \& Mattner, P.E. (1976) Immunization of ewes to oestrogens: effects on the oestrous cycle and parturition. Theriogenology 6, 607, Abstr.

Dean, P.D.G., Exley, D. \& Johnson, M.W. (1971) Preparation of $17 \beta$-oestradiol-6-(O-carboxymethyl)oxime-bovine serum albumin conjugate. Steroids 18 , 593-603.

Dorrington, J.H., Moon, Y.S. \& Armstrong, D.T. (1975) Estradiol-17 $\beta$ biosynthesis in cultured granulosa cells from hypophysectomized immature rats, stimulation by follicle-stimulating hormone. Endocrinology 97, 1328-1331.

Edwards, R.G. (1974) Follicular fluid. J. Reprod. Fert. 37, 189-219.

Hillier, S.G. \& Cameron, E.H.D. (1976) Physiological effects of immunity against steroid hormones in the rat. In Physiological Effects of Immunity against Reproductive Hormones, pp. 91-107. Eds R. G. Edwards \& M. H. Johnson. Cambridge University Press, Cambridge.

Lincoln, G.A., Peet, M.J. \& Cunningham, R.A. (1977) Seasonal and circadian changes in the episodic release of follicle-stimulating hormone, luteinizing hormone and testosterone in rams exposed to artificial photoperiods. $J$. Endocr. 72, 337-349.

Makris, A. \& Ryan, K.J. (1975) Progesterone, androstenedione, testosterone, estrone and estradiol synthesis in hamster ovarian follicle cells. Endocrinology 96, 694-701.

Martensz, N.D. (1977) The experimental manipulation of gonadotrophins in non-pregnant sheep by immunization against steroid hormones. Ph.D. thesis, University of Edinburgh.

Martensz, N.D., Baird, D.T., Scaramuzzi, R.J. \& Van Look, P.F.A. (1976) Androstenedione and the control of luteinizing hormone in the ewe during anoestrus. J. Endocr. 69, 227-237.

Martensz, N.D., Scaramuzzi, R.J. \& Van Look, P.F.A. (1979) Plasma concentrations of luteinizing hormone and follicle-stimulating hormone during anoestrus in ewes actively immunized against oestradiol-17 $\beta$, oestrone or testosterone. J. Endocr. 81, 261-269.

McCracken, J.A., Uno, A., Goding, J.R., Ichikawa, Y. \& Baird, D.T. (1969) The in vivo effects of sheep pituitary gonadotrophins on the secretion of steroids by the autotransplanted ovary of the ewe. J. Endocr. 45, 425-440.

Moor, R.M. (1974) The ovarian follicle of the sheep: inhibition of oestrogen synthesis by luteinizing hormone. J. Endocr. 61, 455-463.

Moor, R.M. (1977) Sites of steroid production in ovine Graafian follicles in culture. J. Endocr. 73, 143-150.

Pant, H.C., Dobson, H. \& Ward, W.R. (1978) Effect of active immunization against oestrogens on plasma gonadotrophins in the ewe and the response to synthetic oestrogen or LH. J. Reprod. Fert. 53, 241-248.

Rawlings, N.C., Kennedy, S.W. \& Henricks, D.M. (1978) Effect of active immunization of the cyclic ewe against oestradiol-17ß. J. Endocr. 76, 11-19.

Scaramuzzi, R.J. \& Land, R.B. (1978) Oestradiol levels in sheep plasma during the oestrous cycle. J. Reprod. Fert. 53, 167-171.

Scaramuzzi, R.J., Caldwell, B.V., Tillson, S.A. \& Thorneycroft, I.H. (1970) Neutralization of exogenous estradiol activity following active immunization procedures. In Research on Steroids, Vol. 4, pp. 187-196. Eds M. Finkelstein, A. Klopper, C. Conti \& C Cassano. Pergamon Press, Oxford.

Scaramuzzi, R.J., Corker, C.S., Young, G. \& Baird, D.T. (1975) Production of antisera to steroid hormones. In Steroid Immunoassay, pp. 111-122. Eds E. H. D. Cameron, S. G. Hillier \& K. Griffiths. Alpha Omega Alpha Publications, Cardiff.

Scaramuzzi, R.J., Baird, D.T., Clarke, I.J., Davidson, W.G., Martensz, N.D. \& Van Look, P.F.A. (1977) Ovulation and oestrus following active immunisation against ovarian steroids. Acta endocr., Copenh., Suppl. 213, 41, Abstr.

Short, R.V. (1962) Steroids in the follicular fluid and corpus luteum of the mare. A 'two-cell type' theory of ovarian steroid synthesis. J. Endocr. 24, 59-63.

Van Look, P.F.A., Hunter, W.M., Corker, C.S. \& Baird, D.T. (1977) Failure of positive feedback in normal men and subjects with testicular feminization. Clin. Endocr. 7, 353-366.

YoungLai, E.V. \& Short, R.V. (1970) Pathways of steroid biosynthesis in the intact Graafian follicle of mares in oestrus. J. Endocr. 46, 321-331. 